\title{
Permocoleus, New Genus, the First Permian Beetle (Coleoptera) from North America
}

\author{
SARA H. LUBKIN AND MICHAEL S. ENGEL ${ }^{1}$ \\ Department of Earth and Atmospheric Sciences, Snee Hall, Cornell University, Ithaca, NY 14853
}

Ann. Entomol. Soc. Am. 98(1): 73-76 (2005)

\begin{abstract}
Permocoleus wellingtonensis, new genus and new species, is based on an elytron from the Permian Wellington Formation of Oklahoma and is the only Paleozoic record of the order Coleoptera from North America and the oldest record for the New World. Until now, Permian Coleoptera were known only from Europe, Australia, southern Africa, and South America but were conspicuously absent from North America, despite the Wellington Formation being among the most diverse deposits of Permian insects. Permocoleus provides evidence that early beetles were globally distributed.
\end{abstract}

KEY WORDS fossil insects, Coleoptera, Permian, Wellington Formation

The ORDER COLEOPTERA IS NOT just the largest group of insects, but with $>360,000$ described species of modern beetles (Erwin 1991, Liebherr and McHugh 2003), it is also the most diverse order of animals, with representatives in almost every plausible nonmarine habitat. Coleopterans are extremely rare in Paleozoic insect deposits (Ponomarenko 2000). The oldest known fossil beetles were described from Early Permian (Lower Artinskian, $\approx 268 \mathrm{Ma}$ ) deposits in Obora, Czech Republic (Kukalová 1969) and slightly younger deposits of Tshekarda, Russia (Rohdendorf 1944, Ponomarenko 1963). These belong to the family Tshekardocoleidae and are considered true beetles based on their mesothoracic structure (Kukalová 1969). Elytra representing the family Oborocoleidae also are recorded from Obora, but because no other structures are preserved, the oborocoleids cannot be conclusively identified as beetles, although such a placement seems likely.

Late Permian beetles are classified in the families Permocupedidae, Asiocoleidae, Rhombocoleidae, and Schizocoleidae, and these are known from South America (Pinto 1987), southern Africa (Geertsema and van der Heever 1996), Australia (Tillyard 1924), and eastern Europe (Martynov 1932, 1937; Rohdendorf 1944, 1961; Ponomarenko 1963, 2000, 2003; Kukalová 1969). This distribution of early fossil Coleoptera has been anomalous. The Early Permian deposits of Elmo, KS, and Midco, OK, are among the most prolific of all Permian deposits for insects (Carpenter 1992, Rasnitsyn and Quicke 2002, Grimaldi and Engel 2005), but Paleozoic beetles were absent from North America. The oldest previously known North Amer-

${ }^{1}$ Department of Ecology and Evolutionary Biology, Snow Hall, 1460 Jayhawk Blvd., University of Kansas, Lawrence, KS 66045-7523. ican Coleoptera were those from the Late Triassic (Carnian, $\approx 230 \mathrm{Ma}$ ) of the eastern United States (Fraser et al. 1996).

Herein, a single elytron from the Wellington Formation of Noble County, Oklahoma, is described and figured. The specimen is the earliest occurrence of Coleoptera in the Western Hemisphere and is the only Permian beetle known from North America.

\section{Geology/Stratigraphy}

The Wellington Formation (Cragin 1896) is of Artinskian age (269-260 Ma) and extends from south central Kansas to northern Okalahoma. The formation is well known for a rich fossil insect fauna that was extensively described by the late F.M. Carpenter, mostly from the Elmo deposits in Kansas but also from the Midco locality in Oklahoma (Carpenter 1947, 1979). The evenly bedded shales and dolomites, and the gray to green lenticular sandstones of the Wellington Formation in Oklahoma have been interpreted as a saline tidal flat environment with interdispersed channels, lakes, and ponds (Olson 1970, Shelton 1979, Schultze 1985). Although in general the shales and sandstones of the Wellington Formation are not fossiliferous (Raasch 1946), a remarkable assemblage of fossil insects is present (Carpenter 1947, 1979; Tasch and Zimmerman 1959, 1962; Tasch 1961).

\section{Systematic Paleontology}

\section{Order COLEOPTERA (L.)}

Permocoleus, n. gen.

Diagnosis. Elytron long and narrow with rows of semiquadrate cells between veins. Five major veins 


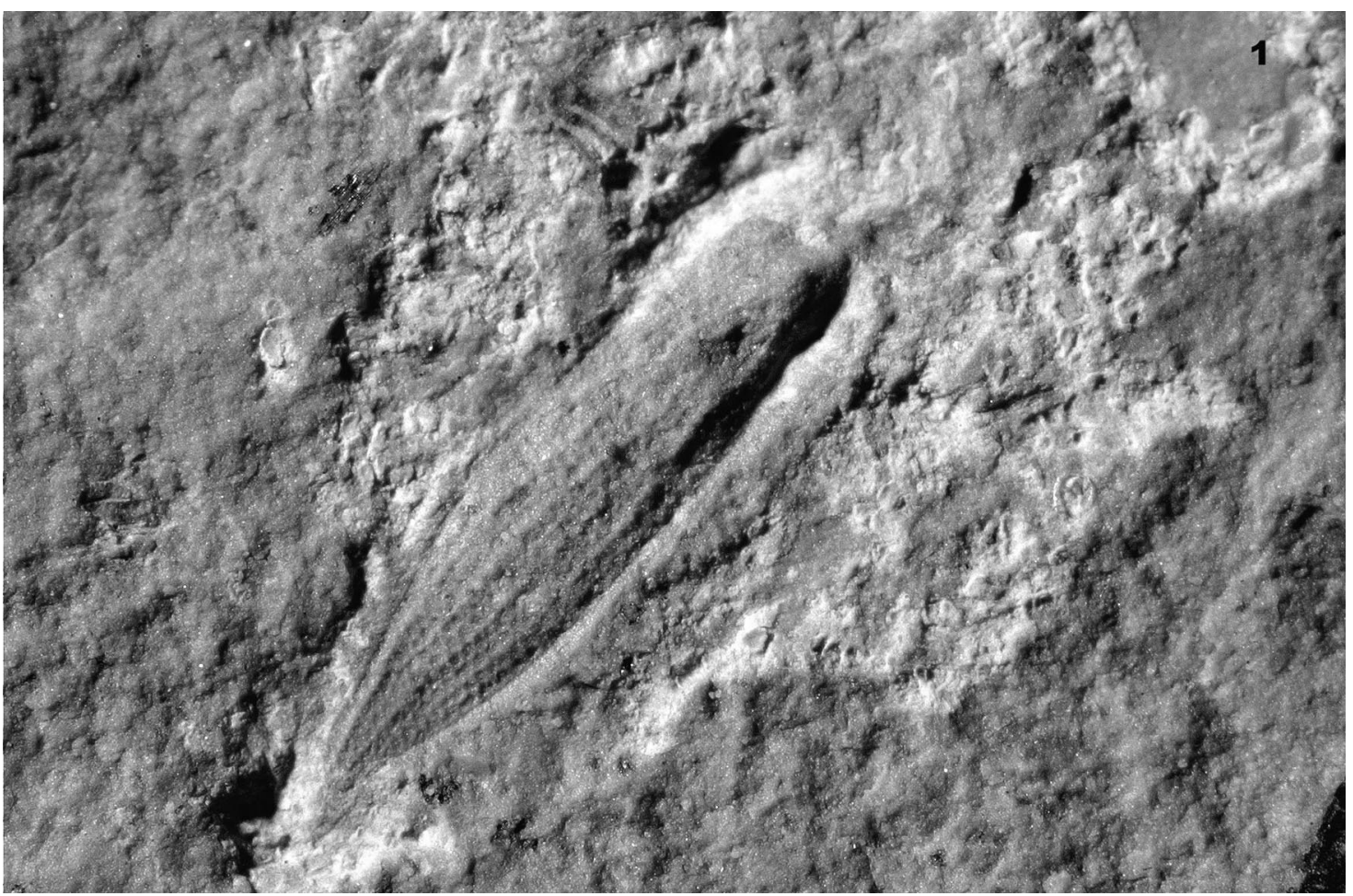

Fig. 1. Photograph of holotype of P. wellingtonensis, n. gen. and n. sp.

(C, Sc, Rs, M, and $\mathrm{CuA}$ ) distinguishable and roughly parallel to elytral margins. Vein Rs branches posteriorly. Two rows of cells are present between veins $\mathrm{C}$ and Rs, between branches of vein Rs, and between veins $\mathrm{M}$ and $\mathrm{CuA}$. Two complete rows and one partial row of cells are present between veins Rs and M. Cell rows coalesce between Rs-M and M-CuA into a single row near wing apex. Vein $1 \mathrm{~A}$ present. One vein meets C near apex.

Permocoleus differs from members of Permocupedidae primarily in that in the former vein Rs is present and branches, whereas in Permocupedidae vein Rs is absent. Permocoleus differs from Tshekardocoleidae and Oborocoleidae in that the venation is not as complete and Rs is the only radial vein present. Body is unknown.

Stratigraphical and geographic distribution, Lower Permian (Artinskian) of Oklahoma, United States.

Type Species. Permocoleus wellingtonensis n. sp.

Permocoleus wellingtonensis Lubkin \& Engel, n. sp. (Figs. 1-2)

Diagnosis. As for the genus with the following additions: total length as preserved $4.5 \mathrm{~mm}$; maximal width as preserved $1.15 \mathrm{~mm}$ (length/width ratio of elytron $\approx 4.0$ ). Small elytron with vein $1 \mathrm{~A}$ incomplete. Several partial rows of cells present on distal edge of elytron. Veins $\mathrm{M}$ and $\mathrm{CuA}$ almost touching at posterior end.
Type Material. HOLOTYPE: MCZ 31136, single elytron from Oklahoma: Noble County: Section 23 (Tasch Noble V; Tasch 1961). Wellington Formation, Lower Permian (Lower Artinskian, 269-260 Ma). The specimen resided among unsorted Permian material in Harvard's Museum of Comparative Zoology for $>30$ yr. Carpenter never referred to the specimen, and it is labeled "Coleoptera?" indicating a one-time uncertainty about its identity.

Etymology. The generic name refers to the Permian age of the specimen, whereas the specific epithet is for the Wellington Formation.

\section{Discussion}

The specimen is more similar to the elytra of later Permian Coleoptera than it is to the more elaborate elytra of the coleopteroids from Obora; therefore, it is tentatively placed in Coleoptera proper. Of the Permian Coleoptera, this species most resembles members of Permocupedidae, especially the South American species Kaltanocupes ponomarenkoi (Pinto 1987). However, the unique pattern of venation distinguishes this specimen from Permocupedidae and all other known Permian beetle families. Given that the specimen is among the oldest of the Coleoptera, it is perhaps surprising that it seems to more closely resemble the reduced venation of typical beetles rather than the elaborate venation of Protocoleoptera. Given the incompleteness of the material at hand, it is impossible 


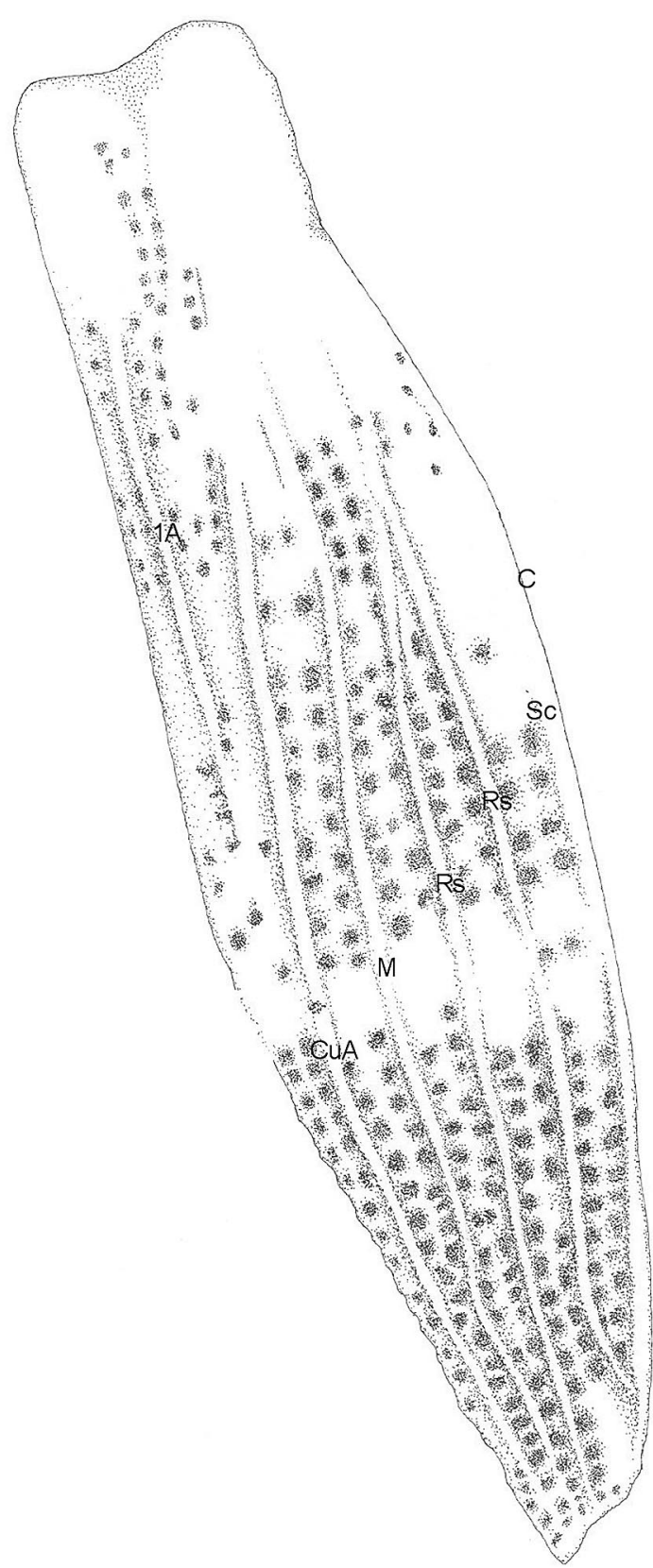

Fig. 2. Line illustration of holotype of P. wellingtonensis, n. gen. and n. sp.

to place the specimen definitively and, therefore, to draw conclusions concerning vein evolution. Hopefully, continued exploration of the Paleozoic of North America will reveal more completely preserved specimens and a greater diversity of early beetles and beetle-like relatives. Despite the incomplete preservation, however, $P$. wellingtonensis represents an important geological and biogeographical record for understanding early beetle evolution and provides a glimpse into the beginnings of Nature's "inordinate fondness."

\section{Acknowledgments}

We thank David A. Grimaldi (American Museum of Natural History) for comments and for support of this study, Tam C. Nguyen (American Museum of Natural History) for assistance with photography, and Phil Perkins (Museum of Comparative Zoology, Harvard University) for arranging the loan. Partial support was provided by a graduate research fellowship from the National Science Foundation to S.H.L. and by a Kansas Technology Corporation-NSF EPSCoR grant (KAN29503) and NSF EF-0341724 to M.S.E. This is contribution \#3396 of the Division of Entomology, Natural History Museum and Biodiversity Research Center, University of Kansas.

\section{References Cited}

Carpenter, F. M. 1947. Lower Permian insects from Oklahoma, Part I. Introductions and the orders of Mecoptera, Protodonata and Odonata. Am. Acad. Arts Sci. 76: 25-53.

Carpenter, F. M. 1979. Lower Permian insects from Oklahoma, Part II. Orders Ephemeroptera and Palaeodictyoptera. Psyche 86: 261-290.

Carpenter, F. M. 1992. Treatise on invertebrate paleontology, part R, Arthropoda 4, vol. 4: superclass Hexapoda. Geological Society of America, Lawrence, KS.

Cragin, F. W. 1896. The Permian system in Kansas. Colo. College Studies 6: 1-48.

Erwin, T. L. 1991. How many species are there?: revisited. Conserv. Biol. 5: 330-333.

Fraser, N. C., D. A. Grimaldi, and P. E. Olsen. 1996. A Triassic Lagerstatte from eastern North America. Nature (Lond.) 380: 615-619.

Geertsema, H., and J. A. van der Heever. 1996. A new beetle, Afrocupes firmae gen. et sp. nov. (Permocupedidae), from the Late Palaeozoic Whitehill Formation of South Africa. S. Afr. J. Sci. 92: 497-499.

Grimaldi, D., and M. S. Engel. 2005. Evolution of the insects. Cambridge University Press. Cambridge, United Kingdom.

Kukalová, J. 1969. On the systematic position of the supposed Permian beetles, Tshecardocoleidae [sic], with a description of a new collection from Moravia. Sb. Geol. Ved. Rada. P. Paleontol. 11: 139-161.

Liebherr, J. K., and J. V. McHugh. 2003. Coleoptera (beetles, weevils, fireflies), pp. 209-203. In V. H. Resh and R. T. Cardé [eds.], Encyclopedia of insects. Academic Press, San Diego, CA.

Martynov, A. V. 1932. Permian fossil insects of the Arkhangelsk District. Trans. Paleontol. Inst. Akad. Nauk. SSSR 2: 83-96.

Martynov, A. V. 1937. Permian Fossil Insects from Kargala and their relationships. Trans. Paleontol. Inst. Akad. Nauk. SSSR 7: 1-92.

Olson, E. C. 1970. New and little known genera and species of vertebrates from the Lower Permian of Oklahoma. Fieldiana Geol. 18: 359-434.

Pinto, I. D. 1987. Permian insects from Paraná Basin, south Brazil IV Coleoptera. Pesquitas 19: 5-12.

Ponomarenko, A. G. 1963. Paleozoic beetles of Cupedidae from the European USSR. Paleontol. Zh. 1: 70-85.

Ponomarenko, A. G. 2000. New beetles from the Permian of European Russia. Paleontol. J. Suppl. 34: 312-316.

Ponomarenko, A. G. 2002. Superorder Scarabaeidea Laicharting, 1781. Order Coleoptera Linné, 1758. The beetles, pp. 164-176. In A. P. Rasnitsyn and D.L.J. Quicke [eds.], History of insects. Kluwer Academic Publishers, Norwell, MA. 
Vol. 98 , no. 1

Ponomarenko, A. G. 2003. The first beetles (Permosynidae, Coleoptera) from the upper Tatarian of European Russia. Paleontol. Zh. 2: 65-68.

Raasch, G. O. 1946. The Wellington Formation in Oklahoma. Ph.D. dissertation, University of Wisconsin, Madison.

Rasnitsyn, A. P., and D.L.J. Quicke. 2002. History of insects. Kluwer Academic Publishers, Dordrecht, The Netherlands.

Rohdendorf, B. B. 1944. A new family of Coleoptera from the Permian of the Urals. Dolk. Akad. Nauk. SSSR 44: 252-253.

Rohdendorf, B. B. 1961. Paleozoiske nasekomye kuznetkogo basseina. Akademia Nauka, Moscow, Russia.

Schultze, H. P. 1985. Marine to onshore vertebrates in the Lower Permian of Kansas, and their paleoenvironmental implications. Paleont. Control 113: 1-18.
Shelton, J. W. 1979. Geology and mineral resources of Noble County, Oklahoma. Okla. Geol. Surv. Bull. 128.

Tasch, P. 1961. Vertical extension of mid-continent Leonardian insect occurrences. Science (Wash. DC). 135: 378 379.

Tasch, P., and J. R. Zimmerman. 1959. New Permian insects discovered in Kansas and Oklahoma. Science (Wash. DC). 130: 1656.

Tasch, P., and J. R. Zimmerman. 1962. The AsthenohymenDelopterum bed -a new Leonardian insect horizon in the Wellington of Kansas and Oklahoma. J. Paleont. 36: 13191333.

Tillyard, R. J. 1924. Kansas Permian insects. Part 1. The geologic occurrence and environment of the insects. Am. J. Sci., 5th Ser. 7: 171-209.

Received 26 April 2004; accepted 7 October 2004. 